\title{
Alternatif Pengelolaan Bantuan Operasional Kesehatan untuk Peningkatan Kesehatan Ibu dan Anak Cakupan K1-K4
}

\author{
Rita Ayu Yolandia ${ }^{1}$, Hedy Hardiana ${ }^{2}$ \\ ${ }^{1}$ Program Magister Kesehatan Masyarakat Sekolah Tinggi Ilmu Kesehatan Indonesia Maju (STIKIM) \\ Jln. Harapan Nomor 50, Lenteng Agung - Jakarta Selatan 12610 \\ Email: 1ryolandia1609@gmail.com, hedy.hardiana@gmail.com
}

\begin{abstract}
Abstrak
Pengelolaan dana Bantuan Operasional Kesehatan (BOK) untuk peningkatan Kesehatan Ibu dan Anak khususnya pada K1 -K4 masih belum optimal, karena sebagian besar Pengelolan dana BOK digunakan untuk kegiatan penunjang dan upaya kesehatan masyarakat, dalam hal ini bantuan pemerintah pusat kepada pemerintah daerah untuk mendukung operasional puskesmas dalam rangka pencapaian program kesehatan prioritas nasional, khususnya kegiatan promotif preventif sebagai bagian dari upaya kesehatan masyarakat. Penelitian ini merupakan penelitian kualitatif dengan pendekatan studi kasus. Informan dalam penelitian ini meliputi Kepala Bidang Pelayanan Kesehatan masyarakat, Kepala Puskesmas dan Bidan Kordinator sebagai informan Kunci. Pengumpulan data dilakukan dengan metode indepth interview. Hasil temuan dalam penelitian ini adalah adanya 4 masalah utama yaitu Keterbatasan Sumber Daya Manusia, khusunya dalam pengelolaan dana Bantuan Operasional Kesehatan dan peningkatan cakupan/kegiatan Kesehatan Ibu dan Anak di masing-masing wilayah puskesmas, Beban Kerja Sumber daya manusia puskesmas yang tidak sebanding dengan jumlah Sumber daya manusianya, Terbatasnya dana bok untuk pembiayaan kegiatan dan Terlambatnya dana Bantuan Operasional Kesehatan untuk cair. Hal ini karena laporan kegiatan puskesmas yang terlambat. Berdasarkan hasil analisa Urgency, Serious dan Growth (USG), dan Strategies Planning Matrix (QSPM) didapatkan prioritas usulan alternatif rekomendasi kebijakan operasional untuk meningkatkan Cakupan K1- K4 pada program Kesehatan Ibu dan Anak yaitu : Usulan alternative rekomendasi terpilih adalah Kebijakan Pengalokasian dana BOK khususnya untuk KIA, Pengusulan Adanya kebijakan Kegiatan Rutin GEMPOR S2 (gerakan Menyelesaikan Laporan 1 jam 1 hari).
\end{abstract}

Kata Kunci: Bantuan Operasional Kesehatan, Kesehatan Ibu dan Anak, Pelayanan

\begin{abstract}
Health Operations Assistance fund management for improving maternal and child health in particular in K1 - K4 is not optimal, Because most of the management of BOK funds are used for supporting activities and public health efforts, in this case the central government assistance to local governments to support the operation of Puskesmas in the framework of the achievement of health programs National priorities, in particular preventive promotive activities as part of public health efforts. This research is a qualitative study with a case study approach. The informant in this research includes the head of Public health service, head of Puskesmas and midwife of Kordinator as key informant. Data collection is done by the method of interview indepth. The findings in this study are the 4 main problems of human resources limitation, especially in the management of health operations assistance and increase the coverage/activities of maternal and child health in each area of Puskesmas, Workload of human Resources health care which is not comparable to the number of resources, is limited to the health operational assistance for the financing of activities and the delay of health operations assistance for liquids. This is due to reports of late health clinics. Based on the results of the analysis of Urgency, Serious and Growth (USG), and Strategies Planning Matrix (QSPM) obtained the priority of alternative proposed operational policy recommendations to increase the scope of K1-K4 on maternal and child health program: proposed Alternative recommendation is selected BOK's fund allocation policy in particular for KIA, the proposal for routine activities of GEMPOR S2 policy (completion of the report 1 Hour 1 day).
\end{abstract}

Keywords : Health operational assistance, Maternal and child health, Service 


\section{Pendahuluan}

Pemerintah Indonesia dalam hal ini Kementrian Kesehatan Berupaya untuk mewujudkan derajat masyarakat yang setinggi tingginya pemerintah menyelenggarakan upaya kesehatan yang terpadu dan menyeluruh dalam bentuk upaya kesehatan perorangan dan upaya kesehatan masyarakat. Upaya tersebut diselenggarakan dengan pendekatan kegiatan yang bersifat promotif, preventif, kuratif dan rehabilitatif yang dilaksanakan secara terpadu, menyeluruh, dan berkesinambungan untuk memelihara dan meningkatkan derajat kesehatan. Pemerintah bertanggung jawab merencanakan, mengatur, menyelenggarakan, membina, dan mengawasi penyelenggaraan upaya kesehatan yang merata dan terjangkau oleh masyarakat ${ }^{1}$

Menurut Kementrian Kesehatan pada tahun 2010 terdapat 8.967 Puskesmas 22.273 Pustu serta Poskesdes dan 2666.827 Posyandu di Indonesia. Namun demikian masih banyak permasalahan yang dihadapi oleh Puskesmas dan Jaringannya dalam upaya meningkatkan status kesehatan di wilayah kerjanya, permasalahan tersebut antara lain adalah keterbatasan dana operasional untuk upaya kesehatan, Bila Permasalahan ini terus berlanjut dikhawatirkan akan berdampak pada penurunan derajat kesehatan masyarakat. ${ }^{2}$

Menurut Undang-undang Nomor 23 Tahun 2014, Desentralisasi adalah penyerahan wewenang pemerintah oleh Pemerintah kepada daerah otonom untuk mengatur dan mengurus urusan pemerintah dalam sistem Negara Kesatuan Republik Indonesia. Hal ini akan sangat berpengaruh terhadap pelaksanaan pembangunan kesehatan, dimana daerah diberi wewenang dalam merencanakan melaksanakan pembangunan kesehatan dibidang kesehatan sesuai dengan kebutuhan, situasi dan kondisi masing-masing daerah yang bertujuan untuk meningkatakan derajat kesehatan dan pelayanan kesehatan serta meningkatkan kemandirian masyarkat di bidang kesehatan dalam rangka meningkatkan kesejahteraan masyarakat. ${ }^{3}$

Pembiayaan kesehatan bertujuan untuk penyediaan pembiayan kesehatan yang berkesinambungan dengan jumlah yang mencukupi, teralokasi secara adil, dan termanfaatkan secara berhasil dan berdaya guna untuk menjamin terselenggarakannya pembangunan kesehatan agar meningkatkan derajat kesehatan setinggi-tingginya, salah satu bantuan pelayanan kesehatan masyarakat yaitu dana Bantuan Operasional Kesehatan (BOK). ${ }^{4}$

Berbagai masalah yang di hadapi oleh tenaga kesehatan di Puskesmas beserta jaringannya dalam upaya meningkatkan status kesehatan masyarakat, termasuk dalam upaya peningkatan kesehatan ibu dan anak, adapun faktor dari masalah tersebut umumnya terkait dengan jumlah tenaga kesehatan di Puskesmas, fasilitas kesehatan termasuk sarana dan prasarananya, akses ke tempat fasilitas kesehatan, keterbatasan Bantuan operasional dan faktor lainnya yang dapat mengakibatkan hambatan/gangguan dalam pemberian pelayanan kesehatan di Puskesmas. ${ }^{5}$

BOK merupakan bantuan pemerintah pusat kepada pemerintah daerah untuk mendukung operasional puskesmas dalam rangka pencapaian program kesehatan prioritas nasional, khususnya kegiatan promotif preventif sebagai bagian dari upaya kesehatan masyarakat. Bantuan ini diharapkan mampu meningkatkan kinerja dan fungsi Puskesmas dan jaringannya terutama dalam upaya Puskesmas yang bersifat promotif dan preventif. Kegiatan yang dibiayai oleh BOK umumnya untuk menjangkau pelayanan di lapangan/luar Puskesmas yang selama ini belum tersentuh secara maksimal. ${ }^{4}$

BOK diturunkan merupakan salah satu terobosan program dalam mengurangi Angka Kematian Ibu dan Bayi, target tersebut merupakan acuan keberhasilan dari program kesehatan reproduksi, sehingga BOK yang di Puskesmas diharapkan mendukung penurunan Angka Kematian Ibu dan Bayi seperti yang tertuang dalam Target SDGs.

Tahun 2010 adalah awal peluncuran program BOK ini, Pada tahun 2010 penyaluran BOK langsung ke Puskesmas melalui mekanisme Bantuan Sosial (Bansos) dan tahun 2011 penyaluran BOK diberikan kepada Dinas Kesehatan Kabupaten/ Kota melalui mekanisme Tugas Pembantuan (TP). Sedangkan untuk tahun $2012-2015$ penyaluran BOK juga menggunakan mekanisme Tugas Pembantuan (TP). ${ }^{5}$ Dan Kebijakan BOK ini berlangsung sampai tahun 2016 dengan adanya pengalihan anggaran di pusat yang semula bersumber dari dana tugas pembantuan menjadi dana Alokasi Khusus non fisik bidang Kesehatan (Tahun 2016). 
Adapun besaran alokasi dana BOK dari tahun 2010 sampai tahun 2017 mengalami peningkatan, yaitu dari 226 Miliar menjadi Rp 4,6 Triliun Hal ini diikuti dengan kenaikan target jumlah Puskesmas yang mendapatkan alokasi dana BOK, yaitu 8737 unit Puskesmas (tahun 2010) menjadi 9767 Puskesmas (tahun 2016). ${ }^{6}$

Sejak dana BOK diluncurkan, belum pernah dilakukan evaluasi terhadap Pengelolaandana BOK untuk kegiatankegiatan yang khususnya terkait dengan pelayanan kesehatan Ibu dan Anak. Apakah dana BOK tersebut memberikan dukungan dan kontribusi terhadap pembiayaan puksesmas dan apakah cakupan pelayanan kesehatan masyarakat di puskesmas khususnya untuk pelayanan kesehatan ibu dan anak dapat meningkat. ${ }^{6}$

Program pelayanan Kesehatan Ibu dan Anak (KIA) merupakan salah satu program pelayanan kesehatan dasar. Pelayanan KIA menjadi tolak ukur dalam Standar Pelayanan Minimal (SPM), dimana Upaya kesehatan ibu dan anak adalah upaya di bidang kesehatan yang menyangkut pelayanan dan pemeliharaan ibu hamil, ibu bersalin, ibu menyusui, bayi dan anak balita serta anak prasekolah dan deteksi dini faktor resiko ibu hamil, pemantauan tumbuh kembang balita dan sebagainya. ${ }^{7}$

Penelitian sebelumnya yang berkaitan dengan Pelaksanaan Kebijakan Operasional Kesehatan dalam Cakupan Program KIA di Puskesmas rawat inap koya barat kota jayapura, ditemukan bahwa adanya Keterkaitan antara pengelola yaitu pemegang Program KIA tidak mendapatkan kesepakatan dalam hal penentuan prioritas masalah yang harus diangkat sebagai program unggulan yang cepat memberikan efek pada peningkatan cakupan KIA, dalam proses penyaluran dana yang tidak merata di program dan masih harus menyesuaikan dengan kegiatan prioritas karena masih banyak kegiatan yang harus dilaksanakan melalui dana BOK. $^{8}$

Rumuasan masalah dalam penelitian ini adalah berdasarkan hasil studi pendahuluan pengelolaan dana BOK tahun 2016 dan 2017 sebagian besar digunakan untuk kegiatan penunjang dan upaya kesehatan masyrakat. Dana BOK tahun 2016 dan 2017 dimanfaatkan untuk upaya KIA dalam menunjang penurunan AKI dan AKB belum
Optimal, meskipun hampir semua Puskesmas terdapat kasus kematian Ibu dan Kematian Bayi, rata-rata pengelolaan dana BOK untuk upaya KIA dimasing-masing Puskesmas cenderung rendah, pada tahun 2016 rata-rata pengelolaan untuk upaya KIA sebesar 5,7\%.

Berdasarkan Rekapitulasi laporan tahunan pelayanan KIA diketahui bahwa masih banyak cakupan kegitan yang belum memenuhi target di beberapa Puskesmas, Dari 11 kecamatan, 4 kecamatan (Pancoran Mas, Cipayung, Sawangan, dan Bojongsari) melebihi target yang ditetapkan. Bahkan 3 diantaranya (Cipayung, Sawangan dan Bojongsari) menunjukkan data bahwa ibu hamil komplikasi yang ditangani justru melebihi target proyeksi. Sedangkan untuk 7 kecamatan lainnya masih dibawah target yang ditetapkan (Beji, Sukmajaya, Cilodong, Cimanggis, Tapos, Cinere, Limo ). ${ }^{9}$

Berdasarkan Data Dari Profil Kesehatan Kota Depok, Didapatkan Bahwa Pembiayan kesehatan Memegang peranan sangat penting dalam pencapaian tujuan pembangunan kesehatan di Kota Depok. Dari tahun ketahun alokasi anggaran kesehatan selalu meningkat, pada tahun 2010 sebesar 3,29\% dari total APBD kota Depok, pada tahun 2011 sebesar 3,37\% tahun 2012 4,07\%, tahun $21036,5 \%$, tahun 2014 sebesar 8,3\% dan di tahun 2015 sebesar 9\% sedangkan untuk Dana APBN yang di alokasikan dalam bentuk dana BOK sebesar Rp. 3.015.655.000 ( 0.92\%). ${ }^{9}$

Realisasi atau serapan dana BOK untuk Puskesmas di kota Depok dari tahun 2010 meningkat sebesar 25,56\%. Dengan tingginya serapan dana tersebut dari tahun ke tahun, seharusnya di imbangi dengan peningkatan Cakupan K1 dan K4, Karena dana BOK dapat digunakan untuk kegiatan promotif dan preventif diluar gedung khususnya transport petugas Puskesmas untuk kunjungan rumah Kehamilan resiko tinggi. ${ }^{9}$

Namun hasil capaian K1 dengan K4 di tahun 2016 mengalami kesenjangan dimana K1 (100\%) dan K4 (95,3\%). Pengelolaan yang tepat sasaran dan melihat capaian program, seharusnya dapat meningkatkan cakupan K1 dan K4 di Puskesmas Wilayah Kota Depok Khususny di Puskesmas Tapos dan Limo yang masih jauh dari target. Untuk itu perlu diketahui Alternatif Kebijakan operasional dalam Pengelolaan BOK untuk meningkatkan Kesehatan Ibu dan anak khususnya cakupan 
K1 dan k4 di Puskesmas Wilayah Kota Depok. $^{9}$

Tujuan penelitian ini adalah menyususn Alternatif Kebijakan Operasional dalam Pengelolaan Bantuan Operasional kesehatan (BOK) untuk Peningkatan Kesehatan Ibu dan Anak di Puskesmas Kota Depok pada Tahun 2018.

\section{Metode}

Penelitian ini merupakan penelitian yang bersifat kualitatif dengan menggunakan pendekatan fenomenologi yaitu dimana peneliti mengkaji secara langsung dan detail kepada beberapa informan. ${ }^{10}$

Rancangan penelitian ini menggunakan analisis kebijakan/Policy Analyical Process versi Patton-Savicky dalam meneliti dalam Pengelolaan Bantuan Operasional kesehatan (BOK) untuk Peningkatan Kesehatan Ibu dan Anak di Puskesmas Kota Depok pada Tahun 2018. ${ }^{11}$

Penelitian ini dilakukan bulan Januari tahun 2018 di Dinkes Kota Depok dan 3 Puskesmas Terpilih yaitu Puskesmas Limo, Puskesmas Cilodong, dan Puskesmas Tapos, Sumber data terdiri dari: 1) Informan; 2) Dokumen. Informan dipilih secara purposive sampling atau teknik sampling disengaja dimana informan dipilih berdasarkan kriteria tertentu (representative) yang ditentukan oleh peneliti. Informan Kunci yaitu mereka yang mengetahui dan memiliki berbagai informasi pokok yang diperlukan dalam penelitian yaitu Kepala Bidang Pelayanan Kesehatan Masyrakat Dinkes Kota Depok (A1), 3 Kepala Puskesmas/ Pengelola Puskesmas (B1, B2, B3) dan 3 Orang Pelaksana Program kesehatan Ibu dan Anak (Bidan Kordinator) di Puskesmas (C1,C2,C3).

Langkah paling awal adalah menyusun panduan wawancara/daftar pertanyaan dan catatan lapangan yang dijadikan dasar pengumpulan data dari informan. Panduan wawancara mencakup: Nama, dan institusi, menjelaskan tujuan studi, latar belakang, bagaimana responden terpilih, kerahasiaan responden akan dijamin, serta menjelaskan keuntungan dari hasil penelitian. ${ }^{12}$ Kemudian persiapan administrasi meliputi peneliti mengurus surat permohonan penelitian ke Dinas kesehatan (Dinkes) Kota Depok dan 3 Puskesmas terpilih. Kemudian dilanjutkan dengan penelitian dengan proses pengumpulan data, reduksi data, sajian data dan penarikan
kesimpulan.Dari kesimpulan yang didapatkan kemudian dilakukan interpretasi. Dengan mengikuti proses penelitian ini.

Teknik pengumpulan data dengan menggunakan wawancara, dokumen, dan observasi. Wawancara dilakukan terhadap informan Kepala bidang pelayanan Kesehatan Masyarakat, kepala Puskesmas, Bidan koordinator, dipilih secara purposive sampling Wawancara dilakukan dengan berpedoman pada panduan wawancara yang telah disiapkan disiapkan. Permasalahan yang hendak dipecahkan melalui wawancara ini adalah peranan Dinkes dan Puskesmas dan keterlaksanaan program KIA selama ini.

Pengumpulan data melalui dokumen dilakukan oleh peneliti dengan pencatatan data-data yang terdapat dalam dokumen KIA, baik mengenai permasalahan yang terjadi, program yang dicanangkan serta pelaksanaan program KIA yang sudah dilakukan. Adapun dokumen yang digunakan dalam penelitian ini adalah buku laporan tahunan KIA, arsip kebijakan BOK, buku pedoman.

Untuk uji kredibilitas hasil penelitian dilakukan teknik pemeriksaan keabsahan data dengan cara; 1) Uji reabilitas melalui perpanjangan keikutsertaan, dan pemeriksaan sejawat melalui diskusi. 2) Uji vadilitas melalui triangulasi sumber data, dan metode. Peneliti melakukan penelitian di lapangan sampai memperoleh data sebanyak-banyaknya maka derajat kepercayaan data yang dikumpulkan dapat ditingkatkan. ${ }^{13}$

Adapun variabel dalam Penelitian ini adalah 1) Sumber Daya Manusia, 2) Sarana dan Prasarana yang ada di Puskesmas yang menunjang kegiatan Program KIA, Dana Operasional yang digunakan untuk kegiatan program KIA 4) Pelaksanaan Program, 5) Upaya Terobosan untuk meningkatkan program KIA.

Tehnik pengolahan dan analisis data dalam penelitian ini peneliti mengolah data secara manual yang digunakan untuk mengklasifikasi proses transkripsi dan pembuatan matriks untuk pengelompokan jawaban responden atas pertanyaan yang diberikan. Data yang terkumpul dari hasil rekaman wawancara mendalam selanjutnya dibuat transkip, dari transkip yang ada lalu disederhanakan dalam bentuk matriks yang kemudian dicari kata kuncinya. Namun tetap peneliti menggunakan teknik analisa secara umum pada pendekatan 
kualitatif yaitu: setelah semua data terkumpul dan diolah, maka tahapan selanjutnya adalah melakukan analisa data dengan teknik analisis isi (content analysis). Dari setiap variabel dan sub variabel diidentifikasikan sesuai dengan analisis kebijakan versi Patton dan Savicky terdiri dari enam tahap yaitu; identifikasi masalah, tentukan kriteria evaluasi, identifikasi alternatif kebijakan, evaluasi alternatif kebijakan, sajikan alternatif kebijakan yang sesuai, dan implementasikan alternatif kebijakan yang sesuai. Kemudian diambil kesimpulan untuk memperoleh gambaran tentang topik penelitian. ${ }^{1}$

\section{Hasil dan Pembahasan}

Penelitian kualitatif yang dilakukan terkait dengan alternatif kebijakan operasional dalam Pengelolaan BOK menghasilkan temuan berdasarkan tujuan penelitian yang telah disusun sebelumnya.

Ketenagaan atau Sumber daya manusia merupakan salah satu faktor penting dalam menjalankan suatu program atau atau kegiatan. Menurut Van Horn dan Van Meter dalam suatu Subarsono (2012), Agustino (2008) dan Nawawi (2009), dukungan sumber saya manusia dibutuhkan dalam melaksanakan suatu kebijakan.

Sesuai Pada tujuan Teknis BOK tahun 2017, maka dibentuk tim pengelola dana BOK tingkat Dinas Kesehatan Kota Depok yang disahkan oleh Walikota dan Kepala Dinas Kesehatan Kota Depok, Selain tim pengelola BOK tingkat Dinas Kesehatan, maka dibentuk tim pengelola BOK tingkat Puskesmas yang disahkan melalui surat Keputusan Kepala Dinas Kesehatan Kota Depok, dimana tiap Puskesmas di Kota Depok, memiliki dua orang sebagai pengelola BOK, yaitu Ketua dan Pengelola Keuangan. Tim pengelola BOK Dinas Kesehatan bertugas memverivikasi, memantau dan mencairkan dana BOK ke Puskesmas serta mengawasi pelaksanaan BOK di 35 Puskesmas Se- Kota Depok.

Berdasarkan Wawancara dengan 3 orang pengelola BOK di Puskesmas Cilodong, Puskesmas Tapos, dan Puskesmas Limo mengatakan Jumlah tenaga atau SDM yang mengelola dana BOK di tahun 2017 masih kurang, Berikut Hasil wawancara dengan Responden:

"Masih kurang, karena di PKM Tapos Ini hanya ada 4 Bidan"(B2)
"Di puskesmas Ini Masih Kurang Untuk tenaga perawat, namun untuk Bidan dan Dokter sudah Cukup, serta untuk Tenaga kesehatan di lab masih kurang." (C1)

"Di puskesmas Cilodong ada 45 nakes, Bidannya ada 5 (D3 Kebidanan), yaitu 2 orang Bidan desa, 1 kegiatan ruti Imunisai dan PKPR yang menjadi inovasi se kota Depok, 1 Administrasi terkait Pembukuan kohort,dan membackup semua Bidan." (D1)

Berdasarkan Peraturan Kementrian kesehatan NO 75. Tahun 2014 tentang Puskesmas bahwa Sumber daya manusia Puskesmas terdiri atas Tenaga Kesehatan dan tenaganonkesehatan. Dimana Jenis dan jumlah Tenaga Kesehatan dan tenaga non kesehatan sebagaimana dimaksud pada ayat (1) dihitung berdasarkan analisis beban kerja, dengan mempertimbangkan jumlah pelayanan yang diselenggarakan, jumlah penduduk dan persebarannya, karakteristik wilayah kerja, luas wilayah kerja, ketersediaan fasilitas pelayanan kesehatan tingkat pertama lainnya di wilayah kerja, dan pembagian waktukerja. ${ }^{15}$

Penelitian yang dilakukan oleh Nurcahyani Tentang Implementasi Kebijakan BOK di Kabupaten Bandung Barat tahun 2011 disimpulkan bahwa pelaksanaan BOK di kabupaten tersebut belum berjalan maksimal karena kurangnya dukungan input (sumber daya manusia, sumber daya dana dan sumberdaya sarana dan prasarana) hal ini dilihat dari aspek kesiapan pegawai, penggunaan dana BOK, dan keterlambatan sosialisai puskesmas. ${ }^{16}$

Di Puskesmas yang memiliki cakupan K4 tertinggi yaitu Puskesmas Cilodong memiliki wilayah kerja lebih sedikit karena hanya 1 desa dengan kondisi jumlah posyandu 15 buah, jika dilihat dari tupoksi sebagai bidan dan pengelola KIA, secara Jumlah sudah cukup. Berikut hasil wawancara dengan Informan :

"Saat ini Jumlah tenaga Kesehatan di PKM cilodong yaitu terdiri dari 45 nakes, termasuk tenaga Bidan yatitu ada 5 orang Bidan (dengan lulusan D3 Kebidanan )"

"Untuk saat ini saya rasa jumlahnya cukup"

Ketidaksesuaian antara kompetensi yang dimiliki oleh pegawai dengan kompetensi yang dibutuhkan dalam jabatan untuk melaksanakan tugas dapat berpengaruh pada rendahnya tingkat keberhasilan tugas. Kompetensi yang diperluikan dalam pengelolaan KIA cukup banyak, dengan demikian dibutuhkan juga banyak penelatihan 
namun dipuskesmas wilayah kota Depok saat ini untuk tenaga kesehataan khususnya bidan sudah mendapatkan banyak pelatihan, berikut hasil wawancara pada responden:

"Sетиа staf selalu mendapatkan pelatihan yang cukup karna unutk pelatihan selalu masuk dalam rencana kerja puskesmas."(A1)

"Masih ada yang belum mendapatkan pelatihan."(B1)

"Iya Sетиa bidan di Puskesmas ini mendapatkan pelatihan seperti APN, PPGDON,CTU"(B2"

Tahap-tahap tertentu dari keseluruhan proses implementasi menuntut adanya sumber daya manusia yang berkualitas sesuai dengan pekerjaan yang diisyaratkan oleh kebiajakn yang telah ditetapkan. Tetapi ketika kompetensinya dan kapabilitas dari sumber sumber daya itu nihil.Maka kinerja kebijakan public sangat sulit untuk diharapkan. ${ }^{17}$

Menurut pengola BOK Dinas Kesehatan Kota Depok, sumber daya manusia (ketenagaan) yang menangani dana BOK di tahun 2017, masih kurang, sebagaimana petikan wawancara sebagai berikut :

" mengingat jumlah Puskesmas di kota Depok yaitu 35 Puskesmas maka untuk mengefektifitaskan waktu unuk turun ke lapangan selain manajemen di dinas jugan kan untuk pembinaan kelapangan ya.. tenaganya.. kalau menurut SK itu masih kurang..." (A1)

Didalam pengelolaan BOK terkait Program kesehatan Ibu dan Anak, peran ketua tim atau pimpinan memiliki andil yang cukup besar, bagaimana visi kedepan, upaya apa saja yang telah dilakukan untuk mengoptimalkan SDM.

Sarana di tiga puskesmas berupa ruang administrasi bagi pengelola keuangan BOK dipuskesmas sebenarnya sudah tersedia. Akan tetapi dari segi prasarana dan alat penunjang seperti komputer, printer, ATK, dll, Masih kurang. Sarana dan prasarana program KIA disemua puskesmas yang diteliti juga masih sangat kurang baik itu ketersediaan ruangan maupun kegiatan diluar gedung, khususnyan kegiatan preventif dan promotif yang kegiatannya dia biayai oleh dana BOK, berikut hasil wawancara dengan responden:

"Sudah cukup namun, masih kurang untuk ruangan."(C1)

"Menurut saya berkaitan dengan kecukupan sarana dan prasarana untuk kegiatan KIA masih kurang." (C2)

"Untuk saat Ini sudah memadahi, ada Ambulance Siaga,(D1)
"Iya untuk sarana dan prasarana sudah cukup. Dan untuk kegitan diluarg gedung, ada pakai ambulance dan pakai kendara sendiri" (D2)

Dalam rangka meningkatkan cakupan pelayanan kesehatan kepada masyarakat berbagai upaya dilakukan dengan memanfaatkan potensi dan sumber daya yang ada di masyarakat. Upaya kesehatan bersumber daya masyarakat (UKBM) diantaranya adalah Posyandu, kelurahan siaga, dan lain sebagainya. Posyandu merupakan salah satu bentuk UKBM yang paling di kenal di masyarakat. ${ }^{18}$ Posyandu menyelenggarakan minimal 5 program prioritas, yaitu kesehatan ibu dan anak, keluarga berencana, perbaikan gizi, imunisasi, dan penanggulangan diare. Untuk memantau perkembangannya, Posyandu dikelompokan ke dalam 4 strata, yaitu Posyandu Pratama, Posyandu Madya, Posyandu Purnama, dan Posyandu Mandiri. Perkembangan jumlah posyandu di Kota Depok dalam kurun waktu 2007-2013 mengalami peningkatan dimana jumlah posyandu 877 buah posyandu tahun 2007 dan pada tahun 2011 sudah mencapai 974 buah posyandu. Tahun 2012 posyandu berjumlah 985 Unit dan yang aktif $727(71,63 \%)$. Tahun 2013 jumlah posyandu 993 unit dan posyandu aktif sebanyak 696 unit. Tahun 2014 jumlah Posyandu 999 unit dan jumlah posyandu aktif sebesar 717 unit. Tahun 2015 jumlah posyandu 1.007 unit dan jumlah posyandu aktif sebanyak 819 unit.

Setelah dilakukan penelitian terdapat berbagai kendala baik dari segi prasarana di dalam gedung maupun diluar gedung, maka peneliti meminta informan untuk menyampain Rekomendasi terkait untuk menyelesaikan permaslahan tersebut Untuk Dinkes berikut hasil dari wawancara pada informan :

"Untuk kedepannya sarana prasarana itu harus dilakukan pengecekan kembali apakah sesuai standar atau blm, harus di kaliberasi, di puskemas ini pun kami sudah melakukan kaliberasi"(B1)

'Diharapkan ada Penambahan SDM dan Pemenuhan Alat alat untuk kegiatan KIA”(B2)

"Iya puskesmas ini ingin bekerja sama dengan dr. Obgine"(C1)

"Rekomendasi dari saya terkait sarana dan prasarana yaitu penambahan fasilitas seperti penambahan ruangan." (C2)

Upaya yang dilakukan oleh 3 Puskesmas yang di teliti untuk meningkatkan kecukupan sarana dan prasarana, diantaranya : 
“Ada, kita setiap tahun selalu mengadakan penganggaran sarana dan prasarana, untuk dananya sendiri turun sesuai dengan perencanaan." (B1)

"Ada, kita setiap tahun selalu mengadakan penganggaran sarana dan prasarana, untuk dananya sendiri turun sesuai dengan perencanaan." (B2)

Setelah dilakukan wawancara di 3 puskesmas, berbagai sumber dana operasional yang ada dipuskesmas Kota Depok terdiri dari 2 macam, yaitu biaya operasional rutin dari APBD (BOP) dan bantuan operasional kesehatan (BOK) dari APBN, masing masing memiliki porsi dan ruang lingkup pemanfaatan tersendiri. BOK banyak dimanfaatkan untuk kegiatan promotif dan preventiv di luar gedung, sedangkan BOP di gunakan sebagai operasional rutin di Puskesmas dan sedikit untuk kegiatan program dalam gedung. Berikut hasil wawancara dengan Responden;

“BOP, BOK, BLUD, JKN, APBD." (A1)

“APBD , BOK \& BLUD.”(B1)

"BOK "(B2)

Tabel 1. Alokasi Anggaran Kesehatan Kota Depok Tahun 2016

\begin{tabular}{|c|c|c|c|}
\hline \multirow[t]{2}{*}{ No } & \multirow{2}{*}{$\begin{array}{l}\text { Sumber } \\
\text { Biaya }\end{array}$} & \multicolumn{2}{|c|}{ Alokasi Anggaran } \\
\hline & & $\begin{array}{l}\text { Jumlah biaya } \\
\text { (RP.) }\end{array}$ & Presentase \\
\hline 1 & APBD & 18.234 .544 .800 & $92.13 \%$ \\
\hline 3 & APBN & 3.722 .239 .000 & $1.13 \% \%$ \\
\hline 4 & $\begin{array}{l}\text { Dana Pajak } \\
\text { Rokok }\end{array}$ & 18.619 .060 .000 & $5.66 \%$ \\
\hline \multirow[t]{2}{*}{5} & DBHCHT & 3.630 .702 .012 & $1.1 \%$ \\
\hline & Total & 44.206 .545 .812 & $100 \%$ \\
\hline
\end{tabular}

Sumber : Dinas Kesehatan Kota Depok tahun 2016

Bila di lihat dari tabel diatas, menunjukan anggaran kesehatan Kota Depok >90 \% berasal dari APBD untuk kegiatan Operasional di 35 Puskesmas. Kota Depok terus mengalami Peningkatan dari tahun 2010 sampai tahun 2017, Sebesar 10.000.000.000.

Kegiatan KIA yang mendukung kunjungan K4 pada tahun 2014-2016 disetiap puskesmas pun sama. Perbedaanya antara tiap puskesmas adalah alokasi dana BOK dibagi berdasarkan jumlah posyandu, luas wilayah dan jumlah masyarakat, artinya dana BOK yang diterima oleh masing-masing puskesmas sudah proposional, sesuai dengan beban kerja di wilayah puskesmas. Berikut hasil wawancara dengan responden:

"kalau khusus BOK saja tidak cukup , tapi jika di gabung, cukup"(B1)

"Sejauh ini Cukup" (Cl)

Pada puskesmas yang cakupan K4 nya rendah petugas hanya berfokus pada kegiatan yang dibiayai saja. Adapun kegiatan yang tidak dibiayai kurang mendapat perhatian. Petugas menjadi kurang bermotivasi untuk mencari sasaran ibu hamil muda sehingga target kunjungan K4 pun tidak tercapai. Berbeda halnya dengan puskesmas yang cakupannya tinggi dengan pengawasan yang baik dari kepala puskesmas, petugas juga mengerjakan kegiatan KIA lain walaupun tidak dibiayai seperti kunjungan ibu hamil resiko tinggi, kegiatan kelas ibu hamil yang tetap berjalan, dan sebagainya.

Permasalaham yang dihadapi oleh ketiga puskesmas yang diteliti salah satunya yaitu ketersediaan dana untuk kegiatan KIA yang terlambat, karna menurut aturan yang berlaku didinas kesehatan dana BOK dapat dicairkan apabila laporan pertanggung jawaban sudah diserahnkan puskesmas ke dinas kesehatan. Sehingga kegiatan berjalan dengan dana talangan dari uang pribadi pengelola keuangan dana BOK puskesmas ataupun dana talangan khas puskesmas, berikut hasil wawancara dengan reponden:

“.dengan keterbatasan waktu untuk setiap Nakes itu hanya boleh keluar 10 kali dalam 1 bln sedangkan pekerjaan kita banyak maka kita tidak dapat Dalam pertanggung Jawabbnya karena harus sesuai dengan aturan." (B1)

"Turunnya lama." (C1)

“Tidak Ada."(D1)

Kebijakan pelayanan antenatal sebagai salah satu input yang sangat penting dalam implementasi pelayanan terpadu di Puskesma. ${ }^{19}$ Dalam kenyataan di kota Depok berdasarkan hasil penelitian menunjukan bahwa kebijakan pelayanan antenatal belum optimal, hal ini ditandai dengan belum teratatanya dengan baik peran para actor atau SDM dalam implementasi kebijakan Pelayanan kesehatan Ibu dan Anak (KIA ) dimana kerjasama lintas sektoral meliputi kegiatan monitoring dan evaluasi kegiatan pelayanan antenatal terpadu Puskesmas secara berkesinambungan belum berjalan dengan baik.

Mengenai pelaksanan kegiatan KIA sudah sesuai dengan yang direncanakan dalam POA 
tahunan dan bulanan berdasarkan keterangan dari informent yaitu sebagai berikut:

"Di awal taun kita membuat rencana, kemudian berbagi tugas seperti siapa yang bagian penyuluhan kemudian bagian pengunjungan rumah, yang menjaga KIA, siapa yang melakukan imunisasi, kegiatan itu dibantu oleh teman teman bidan dan lintas program dan lintas sektoral." (B2)

BOK tahun 2017 dalam pemanfaatan mengalami perluasan bukan hanya untuk operasional puskesmas dan dukungan manajemen, tetapi juga untuk peningkatan peran Dinas Kesehatan Kabupaten/Kota: 1) sebagai fasilitas pelayanan kesehatan Upaya Kesehatan Masyarakat (UKM) sekunder termasuk Balai Kesehatan Masyarakat sebagai UPTnya. $^{20}$

Pemanfaatan dana Bok di 3 Puskesmas yang diteliti untuk kunjungan pada ibu Ibu dan anak. Di puskesmas Cilodong dalam melaksanakan kunjungan Anteanatal pertama melalui kerjasama dengan rumah bersalin atau bidan bidan praktek swasta, dimana Puskesmas memberikan Vitamin untuk ibu hamil dan Buku KIA kepada RB dan BPS tadi dan sebagai imbal balik mereka memberikan data kunjungan pertama ibu hamil ke Puskesmas, sedangkan pemanfaatan dana Bok digunakan untuk Kunjungan Ibu Hamil bayi dan balita resti .

"Manajemen kesehatan Wajib KIA, Kunjungan Ibu hamil, Bayi dan BBL Resti, RPM, pelatihan CIBIMA." (C1)

"Untuk tahun ini cukup, untuk ibu hamil dan balita resiko tinggi." (C2)

"untuk Kunjungan ibu hamil, Bayi, Balita, Resti, Kelas ibu hamil, kunjungan"(D1)

Sebagai salah satu upaya peningkatan cakupan K1 dan K4 di Puskesmas, maka dibutuhkan upaya terobosan.

Dipusekesmas Tapos misalnya dengan melakukan pembinaan kepada Kader, BOK di manfaatkan untuk membiayai transport untuk melakukan advokasi bersama lintas sektoral.

Menurut Informan 2 : (B1)

a. Kita harus rajin pembinaan dilapangan

b. Memberikan Tugas kepada Kader melakukan pelacakan dan pendataan kepada masyarakat

c. Melibatkan kader, Tokoh masyarakat, dan Lintas Sektoral

Perumusan analisis kebijakan dalam penelitian ini mengacu pada konsep Patton dan Savicky yang menggunakan enam langkah dalam merumuskan analisis kebijakan yang sering dikenal dengan a basic policy analysis process.Tahapan-tahapan penerapan konsep Patton dan Savicky dalam penelitian ini. Dapat dijabarkan sebagai berikut: ${ }^{21}$

Langkah pertama yaitu identifikasi masalah. Dalam penelitian ini yang menjadi identifikasi masalah adalah; 1). Keterbatasan SDM, khusunya dalam pengelolaan dana BOK dan peningkatan cakupan/kegiatan KIA di masing-masing wilayah puskesmas, 2) Beban Kerja SDM puskesmas yang tidak sebanding dengan jumlah SDMnya. Setiap puskesmas memiliki beban kerja yang berbeda, tergantung cakupan wilayah dan banyaknya posyadu. 3)Terbatasnya dana bok untuk pembiayaan kegiatan KIA. 4)Terlambatnya dana BOK untuk cair. Hal ini karena laporan kegiatan puskesmas yang terlambat.

Langkah ke dua adalah menetapkan kriteria evaluasi. Berdasarkan hasil USG, peneliti memiliki empat masalah yang menjadi prioritas utama. Berdasarkan analisis dengan menggunakan matrix USG dengan membuat ranking dan total nilai tertinggi, maka faktor yang menjadi prioritas adalah ketersediaan SDM dalam mendukung Kebijakan program KIA di Wilayah Kerja Puskesmas di Kota Depok yang belum memadai. Setelah peneliti mendapatkan faktor utama yang menyebabkan tidak optimalnya pelaksanaan program KIA, maka tahap selanjutnya adalah membuat analisis SWOT.

Analisis swot perlu dilakukan karena analisis swot mencocokkan "fit" antar sumber daya internal dan situasi eksternal. Pencocokan yang baik akan memaksimalkan kekuatan dan peluang dan meminimumkan kelemahan dan ancamannya. Asumsi sederhana ini mempunyai implikasi yang kuat untuk merancang strategi untuk mengoptimalkan pelaksanaan Kebijakan program KIA di Wilayah Kerja Puskesmas di Kota Depok. Berdasarkan hasil matrix USG diperoleh faktor yang menjadi prioritas adalah ketersediaan SDM dalam.

Langkah ke tiga adalah identifikasi alternatif kebijakan. Masalah utama yang menyebabkan belum optimalnya Pemanfatan BOK di Puskesmas Kota Depok adalah keterbatasan SDM khususnya dalam pengelolaan dana BOK. Untuk mengatasi masalah tersebut maka dapat dirumuskan beberapa alternatif kebijakan guna mengoptimalkan pelaksanaan kebijakan Operasional Dalam pemanfaatan BOK. 
Tabel 2. Analisis QSPM (Quantitative Strategic Planning Matrix)

\begin{tabular}{|c|c|c|c|c|c|c|}
\hline \multirow[b]{2}{*}{ No. } & \multirow[b]{2}{*}{ Komponen Dasar } & \multirow[b]{2}{*}{ Bobot } & \multicolumn{2}{|c|}{ Strategi } & \multirow[b]{2}{*}{$\begin{array}{c}\text { Jumlah } \\
\text { Skor }\end{array}$} & \multirow[b]{2}{*}{ Peringkat } \\
\hline & & & $\begin{array}{c}\text { Atractive } \\
\text { Score }\end{array}$ & $\begin{array}{l}\text { Total } \\
\text { Atractive } \\
\text { Score }\end{array}$ & & \\
\hline 1 & $\begin{array}{c}\text { Membuat Kebijakan yang } \\
\text { jelas dalam peningkatan } \\
\text { alokasi anggaran untuk } \\
\text { pengadaan jumlah SDM }\end{array}$ & 0,4 & 3 & 1,2 & 1,6 & 1 \\
\hline 2 & $\begin{array}{l}\text { Membuat kebijakan untuk } \\
\text { melakukan kegiatan rutin } \\
\text { penyelesaian laporan } 1 \text { jam } \\
\text { satu hari sebelum pulang. }\end{array}$ & 0,4 & 3 & 1,0 & 1,4 & 2 \\
\hline 3 & $\begin{array}{c}\text { Peningkatan Standar/ Kualitas } \\
\text { SDM dalam mengelola Dana } \\
\text { BOK }\end{array}$ & 0,4 & 2 & 0,4 & 0,8 & 3 \\
\hline 4 & $\begin{array}{l}\text { Menjalin kerjasama dengan } \\
\text { Instansi pendidikan untuk } \\
\text { menjadi puskesmas sebagai } \\
\text { wahana pendidikan kesehatan. }\end{array}$ & 0,2 & 2 & 0,4 & 0,6 & 4 \\
\hline
\end{tabular}

Adapun beberapa alternatif kebijakan tersebut adalah:

1. Kebijakan Penentuan Penambahan SDM yang khususnya untuk menangani BOK, BP dan anggran lainnya dipisahkan antara SDM khusus dan SDM Kesehatan.

2. Kebijakan Usulan untuk Menerapkan Upaya Kesehatan Bersumber daya Masyarakat (UKBM) dan Menjalin Kerjasama dengan Instansi pendidikan

3. Kebijakan Pengalokasian dana BOK khususnya untuk KIA.

4. Kebijakan terkait Kegiatan Rutin pengumpulan Laporan agar dapat tepat waktu, dapat dilakukan dengan Gerakan menyelesaikan Laporan 1 jam 1 hari atau GEMPOR S2.

Langkah ke empat adalah mengevaluasi alternatif kebijakan yang disusun. Langkah ini khusus digunakan untuk kebijakan yang akan diambil, dengan membuat quantitative strategic planning matrix (QSPM) untuk menentukan prioritas strategi alternatif dalam mengoptimalkan Pemanfaatan BOK. Bentuk dasar dari QSP matriks disajikan dalam tabel 2.

Berdasarkan hasil pada decision stage dapat diketahui bahwa urutan prioritas alternatif strategi yang dapat dilakukan Puskesmas yaitu:

1 Membuat kebijakan untuk melakukan kegiatan rutin penyelesaian laporan 1 jam satu hari sebelum pulang.
2 Membuat Kebijakan yang jelas dalam peningkatan jumlah SDM Khusus pengelola BOK.

3 Petugas Puskesmas melakukan Upaya Kesehatan bersumber daya Masyarakat.

4 Pengusulan Kebijakan Pengalokasian BOK Khusus KIA.

Langkah ke lima yaitu menyajikan alternatif kebijakan yang dipilih. Pada tahap ini peneliti mengajukan alternatif kebijakan yaitu Membuat Kegiatan Rutin dengan melakukan Penyelesaian Laporan 1 Jam 1 hari Sebelum Pulang menjadi prioritas alternative terpilih sebagai alternatif rekomendasi kebijakan operasional Pengelolaan BOK untuk Peningkatan Cakupan K1-K4 di Puskesmas Kota Depok. Keuntungan dari program gerakan Menyelesaikan Laporan 1 jam 1 Hari Sebelum Pulang (Gempor S2) adalah : 1) Petugas Kesehatan mampu menyelesaikan Laporan Rutin Bulanan Capaian Program Puskesmas. 2) Kepala Puskesma dapat menyampaikan laporan Rutin Bulanan Tepat Waktu setiap Bulannya.

Selain itu kemungkinan adanya hambatan yang dihadapi dalam pelaksanaan Gempor S2 seperti: Kurangnya komitmen dan keseriusan tenaga kesehatan dalam menyelesaikan laporan setiap hari

Berdasarkan hasil penilaian dari Dinkes Depok tentang Program Gerakan Menyelesaikan Laporan 1 Jam 1 Hari sebelum pulang, secara garis besar masih Perlu Pertimbangan, berikut Pernyataan Informan Sebagai Berikut : 
“ Berdasarkan hasil pemaparan saya mengganggap perlu, programnya cukup menarik namun masih perlu banyak hal yang perlu di kaji lagi, kami harus mengevaluasi lagi beberapa puskesmas yang lain apakah mengalami permasalahandan kendala yang sama, karena menurut saya jika hanya dari permaslah 3 puskesmas, masih belum kuat untuk membuat SK tersebut"

Langkah keenam konsep Patton dan savicky belum bisa diterapkan mengingat keterbatasan waktu. Peneliti sudah mengajukan dan mengusulkan Program Gerakan menyelesaikan laporan 1 jam 1 hari sebelum Pulang.

\section{Kesimpulan}

Dari hasil pembahasan dapat disimpulkan bahwa kegiatan rutin menyelesaikan Laporan agar dapat tepat waktu dipilih berdasarkan analisa kebijakan dengan metode USG dan QSPM maka terpilih "Program gerakan menyelesaikan Laporan 1Jam 1 Hari Sebelum Pulang " (GEMPOR S2) telah di susun dalam bentuk SK yang berisi Tujuan, Sasaran, Strategi, Monitoring dan Evaluasi.

\section{Saran}

Adapun saran yang bisa diberikan antara lain;Untuk Dinas kesehatan seharusnya menambah SDM di puskesmas yang capaian Targetnya blm tercapai, dan melengkapi sarana dan prasarana di puskesmas maupun kegiatan di luar gedung. Dan Perlu meningkatkan kualitas pelaksanan di puskesmas dan meningkatkan sarana dan prasaran serta penambahan SDM dan perlu adanya kerja sama sesama tenaga kesehatan dalam menyelesaikan laporan puskesmas.

\section{Daftar Pustaka}

1. Republik Indonesia.Undang-Undang No 36 Tahun 2009 Tentang Tenaga Kesehatan.Jakarta;2009.

2. Kementrian Kesehatan Republik Indoensia .Program P4K.Jakarta;2010.

3. Republik Indonesia.Undang-Undang No 32 Tahun 2004 tentang Pemerintah daerah.Jakarta: 2004

4. Peraturan Mentri Kesehatan RI. No 71 tahun 2016 tentang Petunjuk Teknis Penggunaan Dana Alokasi Khusus Nonfisik Bidang Kesehatan tahun Anggaran 2017.Jakarta;2016.

5. Kementrian Kesehatan RI. Peluncuran Dana BOK .Jakarta;2011.

6. Kenetrian Kesehatan RI. Transport Kader.Jakarta;2012.
7. Peraturan Mentri Kesehatan RI. No. 43 Tahun 2016 tentang Penyusunan Formasi Jabatan Fungsional Kesehatan.Jakarta; 2016.

8. Burdames, Anna Aprina. Pelaksanaan Kebijakan Bantuan Operasional Kesehatan dalam Cakupan Program KIA di Puskesmas Rawat Inap Koya Barat Kota Jayapura Fakultas Kesehatan Masyarakat. 2012.

9. Dinas Kesehatan Kota Depok. Profil Kesehatan Kota Depok Tahun 2016.Depok;Dinkes depok;2016.

10. Creswell, Johan W. Research design pendekatan kualitatif, kuantitatif, dan mixed. Yogyakarta: Pustaka; 2010.

11. Sugiyono. Memahami penelitian kualitatif. Bandung: Alfabeta; 2010.

12. Sugiono. Metode penelitian kuantitatif, kualitatif, dan kombinasi (mixed methods). Bandung. Alfabeta; 2011.

13. Bungin, B. Penelitian kualitatif, komunikasi, ekonomi, kebijakan publik, dan ilmu sosial lainnya. Cetakan ke 5. Jakarta: Prenada media group; 2011.

14. Peraturan Mentri Kesehatan RI.No.43 Tahun 2016 Tentang Penyusunan Formasi Jabatan Fungsional Kesehatan. Jakarta ; 2016

15. Nurcahyani, Rita. Implementasi Kebijakan BOK di Kabupaten Bandung Barat;2011. 